
ン授業に対する感情の動向一Twitter のつぶやきを用いた感情分析一

○阿部 夏希 1.2 , 中島健一郎 ${ }^{1}$

(1広島大学, ${ }^{2}$ 日本学術振興会)

キーワード : オンライン授業, COVID-19, 感情分析

COVID-19の感染拡大によって日本では多くの人々の生活が変化し，教 育にも大きな影響を与えた。多くの大学では COVID-19の感染拡大が懸 念されていることを鑑みて, 対面式の授業ではなくオンライン授業に移 行している。しかし，オンライン授業に対処するためには機材準備など 経済的負担の他にも，在宅で生活しながら不慣れな授業をする，あるい は授業を受ける必要があり，さらなる負担の増加になると予想される。 COVID-19による経济的・精神的不安に対処する必要性があるなか，人々 がオンライン授業に対してどのような感情を持っているのかを知ること は有用であろう。そこで本研究では, Twitter のつぶやき（N=3500）を 用いて，オンライン授業に対する人々の感情について検討を行った。オ ンライン授業を含むつぶやきを抽出し感情分析を行った結果, ポジティ ブ0.01\%，ややポジティブ0.02\%，ややネガティブ $58.32 \%$ ，ネガティブ $36.98 \%$ であることが明らかになった。この結果は，人々がストレスを抱 えながらオンライン授業に対処していることを示唆している。
PD-073ＣOVID-19影響下におけるオンライ

PD-074

\section{修学不適応感を持つ大学生に対する 認知行動療法の効果}

○小川さやか ${ }^{1}$, 矢内希梨子 ${ }^{1}$, 田山 淳 $^{2}$

(1長崎大学, ${ }^{2}$ 早稲田大学)

キーワード : 修学不適応感, 認知行動療法

【問題と目的】大学の休退学者の中には, 修学に関して不適応感を感じて いる学生が多い。国内外の大学において抑うつ予防の認知行動療法が行 われているが, 修学不適応感の緩和を目的としたプログラムは開発され ていない。そこで本研究では, 認知行動療法が大学生の修学不適応感を 緩和するという仮説検証を行った。

【方法】同意の得られた40名に e-learning を用いた全 6 回の認知行動療法 を実施した。質問紙に回答をした 34 名（平均年齢19.5歳）を分析対象者 とした。調查項目は, 修学不適応感尺度, 抑うつを測定する BDI-II, 精 神的健康度を測定する GHQ-28を用いた。介入前と介入 1 ケ月後で対応の ある $t$ 検定を実施した。本研究は長崎大学の倫理委員会の承認を得た。 【結果と考察】修学不適応感を持つ大学生に対し認知行動療法を実施した 結果，34名中 22 名に修学不適応感の改善がみられたことから仮説は支持 された。介入前に比べ1 ケ月後の BDI-II および GHQ-28は有意な減少を 示した (BDI-II: $t=8.18, p<0.0001, \mathrm{GHQ}-28: t=5.24, p<0.0001$ )。認知 行動療法により修学不適応感とどのように付き合うか考える機会となり， 抑うつ感の改善と精神的健康の改善に影響したと考えられる。

連絡先 E-mail：ogawa-sa@nagasaki-u.ac.jp

\section{PD-076＼cjkstart筋強直性ジストロフィーにおける症 状評価の差異 : データの二次解析に よる検討}

\author{
○國吉 知子 ${ }^{1}$ \\ (1神戸女学院大学) \\ キーワード：PCIT, マインドフルネス, MAAS
}

目的：適切な子育て態度を習得する行動療法（Eyberg, 1974）である PCIT（親子相互交流療法）には対象の行動をありのままに捉え，観察す るスキルが数多く含まれている。一方，マインドフルネス（以下 MF）は 自他への観察力向上や注意制御能力の獲得をその中核機能とする。本研 究では PCIT セラピスト養成講座（以下 TC）受講前後での MF 特性の 変化を検討し，PCITが「マインドフルな子育て」の行動指針となりうる かを検討した (本学倫理審查承認済 本学教育研究助成金を受け実施)。 方法：TC 受講生（7名）の受講前後での MF 特性の比較を行った。対 照群は非受講群（6 名）の同期間前後での MF 特性の比較を行った。尺 度 : MAAS (Mindful Attention Awareness Scale; 藤野 · 梶村 - 野村, 2015)。TCは PCIT International 準拠の正規マニュアルに基づき, ト レーナー資格を持つ筆者が実施した。

結果：ノンパラメトリック検定の結果, PCIT 群では TC 後 MAAS 得点 に有意な減少傾向（MF上昇）がみられたが，統制群では変化はなかっ た(PCIT 群 $\mathrm{z}=-1.873, p<.10$; 非受講群 $\mathrm{z}=-.946$, n.s.)。 考察：PCIT 習得による MF の上昇傾向が示唆され, PCITがマインドフ ルネスの態度形成に寄与する可能性が窺えた。

連絡先 E-mail：kuniyosi@mail.kobe-c.ac.jp

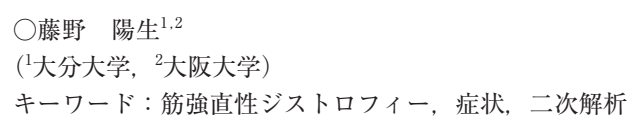

背景 : 筋強直性ジストロフィーは進行性の筋委縮を主症状とするが, 中枢 神経症状を伴う。認知機能障害として, 遂行機能の障害が知られており, 遂行機能障害は自身の病状の評価に影響すると考えられる (Baldanzi, et al., 2011)。本研究では, 過去の研究の二次解析を行い, そのような関連 が見いだされるかを検討する。

方法: 本邦 (Fujino, et al., 2018) におけるデータと, 海外における研究 の公開データ (Hamilton, et al., 2018) を二次解析に使用した。 結果 : 自己評価と他者評価の差異と関連する要因として, 抑うつ $(\mathrm{r}=0.52)$, 患者報告式アウトカム-MDHI $(r=-0.38)$ と関連が示され, 本邦の患者で 見いだされた関連と一致していた。しかし，本邦の患者においては遂行機能 に関わる認知機能検查と関連があったが，海外のデータでは関連が見いださ れなかった。

考察 : 本邦, 英国の患者においても病状の認識の差異が生活上の問題と も関わる要因であることが示唆された。

本研究の実施にあたり，科学研究費17K14067, AMED 難治性疾患実用 化研究事業の支援を受けた。 